\title{
Penilaian Kinerja Karyawan Di Kantor RUPBASAN Kelas II Blitas Dengan Menggunakan Fuzzy Simple Additive Weighted
}

\author{
Desma Syahputra ${ }^{1}$, Fitri Marisa ${ }^{2}$ \\ 1'adesma58@gmail.com, ${ }^{2}$ fitrimarisa@widyagama.ac.id
}

\author{
Program studi Teknik Informatika, Universitas Widyagama, Malang
}

\begin{abstract}
Measurement of a company's performance is very important for future evaluation and planning. Employee performance assessment is absolutely necessary to determine the achievements that each employee wants to achieve. For this reason, each company has a different way of evaluating employee performance. In practice, the assessment of the work performance of employees must be carried out with a good and appropriate method, so that no errors occur in the assessment. The results of the assessment carried out must be able to guarantee fair and satisfactory treatment for the employees assessed, so that in turn it fosters loyalty and morale. There are several tools that are commonly used to conduct employee performance appraisals, namely by the method of apparel performance. However, this method has several problems including the assessment is still vague, halo effects occur, centralized tendencies, influenced by age, race, and gender. A decision support system is a tool that can be used to evaluate employee work performance by improving the assessment methods of apparel performance. Fuzzy Method Simple Additive Weighting was chosen to make an assessment and ranking of employee performance. From the test results, it can be concluded that this application can be implemented for the work performance assessment of contract employees in the Blitar cluster II RUPBASAN class.
\end{abstract}

Intisari -- Pengukuran kinerja suatu perusahaan sangat penting guna evaluasi dan perencanaan masa depan. Penilaian prestasi karyawan mutlak harus dilakukan untuk mengetahui prestasi yang hendak dicapai setiap karyawan. Untuk itu setiap perusahaan mempunyai cara yang berbeda dalam melakukan penilaian prestasi kerja karyawan. Dalam praktiknya, kegiatan penilaian atas prestasi kerja para karyawan harus dilakukan dengan metode yang baik dan tepat, sehingga tidak terjadi kesalahan dalam penilaian. Hasil penilaian yang dilakukan harus dapat menjamin perlakuan yang adil serta memuaskan bagi para karyawan yang dinilai, sehingga pada gilirannya menumbuhkan loyalitas dan semangat kerja. Ada beberapa alat bantu yang sudah umum digunakan untuk melakukan penilaian prestasi kerja karyawan, yaitu dengan metode performance apparsial. Akan tetapi metode ini memiliki beberapa masalah diantaranya adalah penilaian masih bersifat samar, terjadi efek halo, kecenderungan terpusat, dipengaruhi umur, ras dan jenis kelamin. Sistem pendukung keputusan merupakan alat bantu yang dapat digunakan untuk melakukan penilaian prestasi kerja karyawan dengan cara memperbaiki metode penilaian dari performance apparsial. Metode Fuzzy Simple Additive Weighting dipilih untuk melakukan penilaian dan perangkingan prestasi kerja karyawan. Dari hasil pengujian dapat disimpulkan bahwa aplikasi ini dapat diimplementasikan untuk penilaian prestasi kerja karyawan kontrak di kantror RUPBASAN kelas II Blitar.

Kata kunci : Pengukuruan kinerja, Penilaian prestasi, kantor rupbasan,Performance Apparsial,Fuzzy SAW.

\section{PENDAHULUAN}

Pengukuran kinerja suatu kantor sangat penting guna evaluasi dan perencanaan masa depan. Penilaian prestasi karyawan mutlak harus dilakukan untuk mengetahui prestasi yang hendak dicapai setiap karyawan. Apakah prestasi yang dicapai setiap karyawan baik, sedang atau kurang. Penilaian prestasi penting bagi perusahaan untuk menetapkan tindakan kebijaksanaan selanjutnya. Untuk itu setiap perusahaan mempunyai cara yang berbeda dalam melakukan penilaian prestasi kerja karyawan. Penilaian ini tergantung pada kebijakan kantor. Rupbasan kelas II Blitar merupakan sebuah kantor yang bergerak dibidang penyimpanan barang sitaan milik Negara. kantor ini memiliki karyawan yang jumlahnya selalu meningkat, hal ini dikarenakan jumlah permintaan produksi yang semakin bertambah. Kondisi saat ini, penilaian dilakukan dengan mengamati karyawan kemudian data diolah secara manual, dimana masih banyak terjadinya kesalahan dalam penginputan data karyawan dan penilaian prestasi kerja serta membutuhkan waktu yang relatif lebih lama. Terdapat beberapa pendekatan untuk menyelesaikan permasalahan penilaian prestasi karyawan, antara lain dengan menggunakan Multi Attribute Decision Making (MADM) dengan metode Simple Additive Weighting (SAW), Weighted Product (WP), ELECTRE, TOPSIS, Analytic Hierarchy Process (AHP).

"Simple Additive Weighting Approach to Personnel Selection Problem" keterbatasan dari makalah tersebut adalah adalah bahwa SAW mengabaikan fuzziness of 
executivesselama proses pengambilan keputusan. Selain itu, beberapa kriteria dapat memiliki struktur kualitatif atau memiliki struktur yang tidak pasti dan tidak dapat diukur dengan tepat [1].

Sistem pendukung keputusan ini membantu melakukan penilaian setiap karyawan, melakukan perubahan kriteria,dan perubahan nilai bobot [2]. Hal ini berguna untuk memudahkan pengambil keputusan yang terkait dengan masalah pemilihan karyawan berprestasi, sehingga akan di dapatkan karyawan yang paling layak diberi reward atau penghargaan [3].

Dari beberapa pendekatan yang memungkinkan, dipilih pendekatan Fuzzy Multi Attribute Decision Making (FMADM) dengan metode Simple Additive Weighting (SAW). Metode ini dipilih karena metode ini menentukan nilai bobot untuk setiap atribut, kemudian dilanjutkan dengan proses perangkingan [3] yang akan menyeleksi alternatif terbaik dari sejumlah alternatif, dalam hal ini alternatif yang dimaksud adalah yang berhak menerima reward berdasarkan kriteria-kriteria yang ditentukan [3][4]. Alasan lain penggunaan Fuzzy Multi Attribute Decision Making (FMADM) dengan metode Simple Additive Weighting (SAW) karena data penilaian yang diinput tidak harus berupa data crips, berbeda dengan metode Multi Attribute Decision Making (MADM) klasik, dimana input data penilaian harus berupa data crips [5].

Tujuan dari penelitian ini adalah bagaimana melakukan penilaian kinerja karyawan di Ifun Jaya Textile dengan memanfaatkan metode Fuzzy Simple Additive Weighting (FSAW).Diharapkan penilaian kinerja karyawandengan metode FSAWdi Ifun Jaya Textile dapat dilakukan dengan lebih baik dan cepat, sehingga bisa membantu manajemen dalam mengambil sebuah keputusan.

\section{METODE PENELITIAN}

\section{A. Jenis Penelitian}

Penelitian dilakukan di kantor Rupbasan Kelas II blitar dengan membandingkan antara penilaian kinerja karyawan secara manual dengan penilaian kinerja karyawan dengan metode FSAW untuk mengetahui seberapa cepat, akurat dan tepat proses perhitungan yang dilakukan. Untuk melakukan penelitian dilakukan observasi terlebih dahulu di Rupbasan Kelas II blitar dengan membagikan kuesioner dan melakukan wawancara kepada penjabat kantor.

\section{B. Populasi dan Sampel}

Jumlah karyawan di Rupbasan Kelas II blitar pada Desember tahun 2018 adalah 35 orang, adapun jumlah detailnya adalah sebagai berikut :

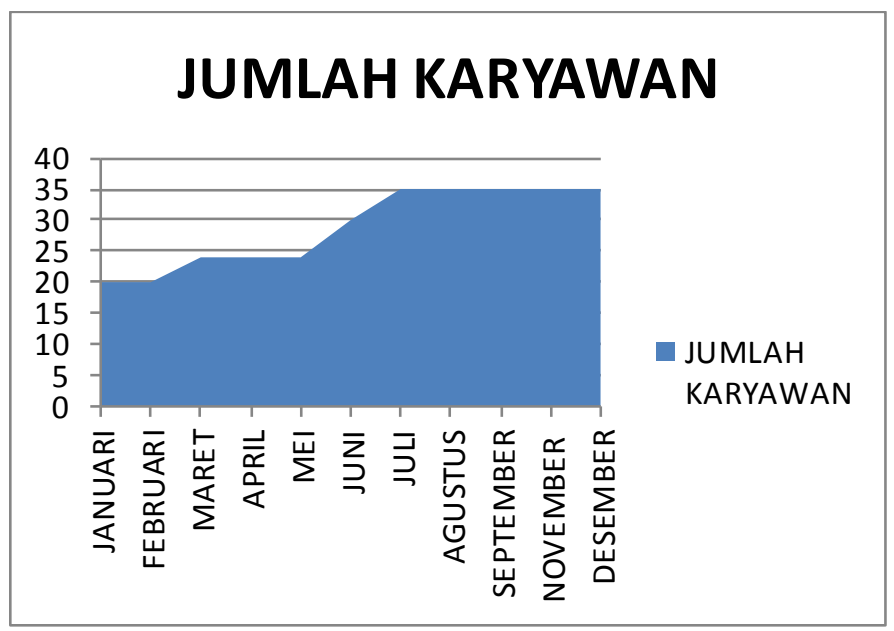

Gambar 1. Jumlah karyawan Rupbasan Kelas II blitar Tahun 2018

Dengan jumlah populasi yang hanya 35 orang, maka seluruh populasi akan digunakan dalam penelitian.

\section{Metode Pengumpulan Data}

Pengumpulan data dilakukan dengan memberikan kuisioner kepada 4 (empat) orang yang terdiri dari pemilik perusahaan, manager operasional, mandor dan bendahara perusahaan. Berikut pertanyaan yang disampaikan pada pre test :

1. Penilaian kinerja karyawan yang saat ini berjalan dapat memberikan informasi yang akurat?

2. Penilaian kinerja karyawan yang saat ini berjalan dapat memberikan hasi yang cepat?

3. Penilaian kinerja karyawan yang saat ini berjalan dapat membantu perusahaan dalam pengambilan keputusan?

4. Proses yang saat ini berjalan dapat memudahkan dalam melakukan penilaian kinerja karyawan?

5. Proses yang saat ini berjalan sudah memberikan analisis yang tepa dan akurat terhadap penilaian kinerja karyawan?

6. Penilaian kinerja karyawan yang saat ini berjalan menggunakan beberapa parameter/variable?

7. Penilaian kinerja karyawan yang saat ini berjalan dapat memberikan keuntungan bagi perusahaan?

Hasil kuisioner tersebut diukur degan skala Likert, yang merupakan bentuk skala penilaian antara 1 (satu) sampai 4 (empat) dengan deskripsi sebagai berikut:

- Angka (1) menyatakan tidak setuju (TS)

- Angka (2) menyatakan kurang setuju (KS)

- Angka (3) menyatakan setuju (S)

- Angka (4) menyatakan sangat setuju (S) 


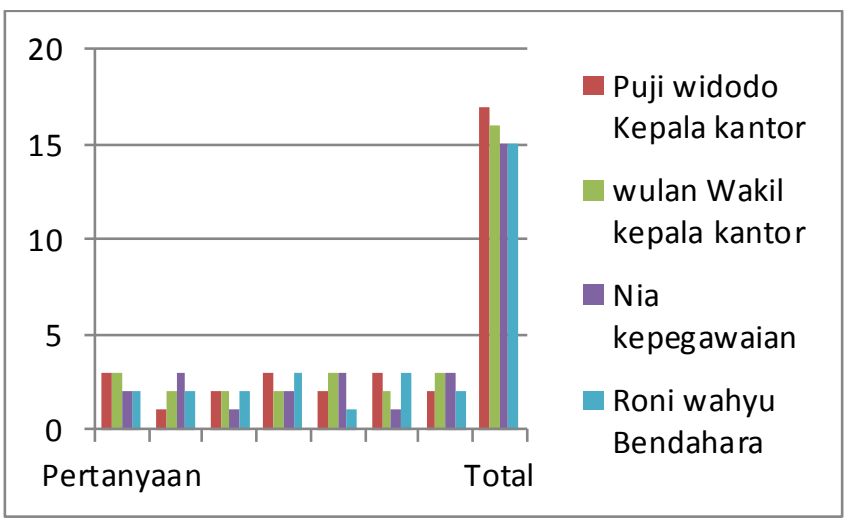

Gambar 2. Hasil Pre Test :

Selain memberikan kuesioner, dilakukan pula wawancara terhadap pemilik perusahaan Ifun Jaya Textile. Wawancara dilakukan untuk mengetahui apa yang menjadi kriteria penilaian kinerja karyawan dan bagaimana pembobotan yang saat ini dilakukan. Dari hasil wawancara yang dilakukan, pemilik perusahaan menetapkan beberapa kriteria dan bobot untuk penilaian kinerja karyawan, yaitu :

Tabel 1. Kriteria dan Bobot Penilaian Kinerja Karyawan di Ifun Jaya Textile

\begin{tabular}{|l|l|l|l|}
\hline No & \multicolumn{1}{|c|}{$\begin{array}{c}\text { Kriteria } \\
\text { Penilaian }\end{array}$} & $\begin{array}{c}\text { Bobot } \\
\text { Preferensi }\end{array}$ & \multicolumn{1}{c|}{ Keterangan } \\
\hline 1 & $\begin{array}{l}\text { Kualitas } \\
\text { kuantitas } \\
\text { kerja }\end{array}$ & $\begin{array}{l}\text { Sangat } \\
\text { Tinggi }\end{array}$ & $\begin{array}{l}\text { Menilai berapa jumlah } \\
\text { dan bagaimana kualitas } \\
\text { pekerjaan yang } \\
\text { telah diselesaikan } \\
\text { karyawan }\end{array}$ \\
\hline 2 & Ketaatan & Tinggi & $\begin{array}{l}\text { Menilai tanggung jawab } \\
\text { terhadap seluruh proses } \\
\text { pelaksanaan } \\
\text { tugas dan ketaatan } \\
\text { terhadap aturan } \\
\text { perusahaan }\end{array}$ \\
\hline 3 & Kerjasama & Cukup & $\begin{array}{l}\text { Menilai tingkat } \\
\text { kemampuan bekerjasama } \\
\text { dengan atasan dan } \\
\text { rekan kerja dalam } \\
\text { melaksanakan tugas }\end{array}$ \\
\hline 4 & $\begin{array}{l}\text { Semangat } \\
\text { kerja }\end{array}$ & Cukup & $\begin{array}{l}\text { Menilai motivasi secara } \\
\text { terus menerus dalam } \\
\text { pelaksanaan tugas } \\
\text { dan antusiasme untuk } \\
\text { pengembangan dirinya }\end{array}$ \\
\hline 5 & $\begin{array}{l}\text { Disiplin } \\
\text { kerja }\end{array}$ & Tinggi & $\begin{array}{l}\text { Menilai ketepatan hadir di } \\
\text { tempat kerja }\end{array}$ \\
\hline
\end{tabular}

D. Teknik Pengolahan Data

Setelah data diperoleh, selanjutnya adalah melakukan perhitungan dengan data tesebut dengan metode FSAW.Untuk menganalisis datahasil angket dilakukan langkah-langkah sebagai berikut:
1. Melakukan identifikasi kriteria.Identifikasi Kriteria

$\mathrm{C} 1$ = Kualitas dan Kuantitas Kerja

C2 Ketaatan

$\mathrm{C} 3$ = Kerjas ama

$\mathrm{C} 4$ = Semangat Kerja

C5 = Disiplin Kerja

Dari bilangan fuzzy bobot yang telah ditentukan dapat dikonversikan ke bilangan crips : Sangat Rendah $(\mathrm{SR})=0$; Rendah (R)=0,25; Cukup (C)=0,5; Tinggi $(\mathrm{T})=0,75$; dan Sangat Tinggi $(\mathrm{ST})=1$.

2. Melakukan konversi bilangan fuzzy ke bilangan crips. Semua kriteria terbagi atas 5 (lima) bilangan fuzzy, yaitu sangat kurang (SK), kurang (K), cukup (C), baik (B), sangat baik (SB). Bilangan-bilangan fuzzy tersebut dapat dikonversikan ke bilangan crips : $\mathrm{SK}=0 ; \mathrm{K}=0,25 ; \mathrm{C}=0,5$; $\mathrm{B}=0,75$; dan $\mathrm{SB}=1$;

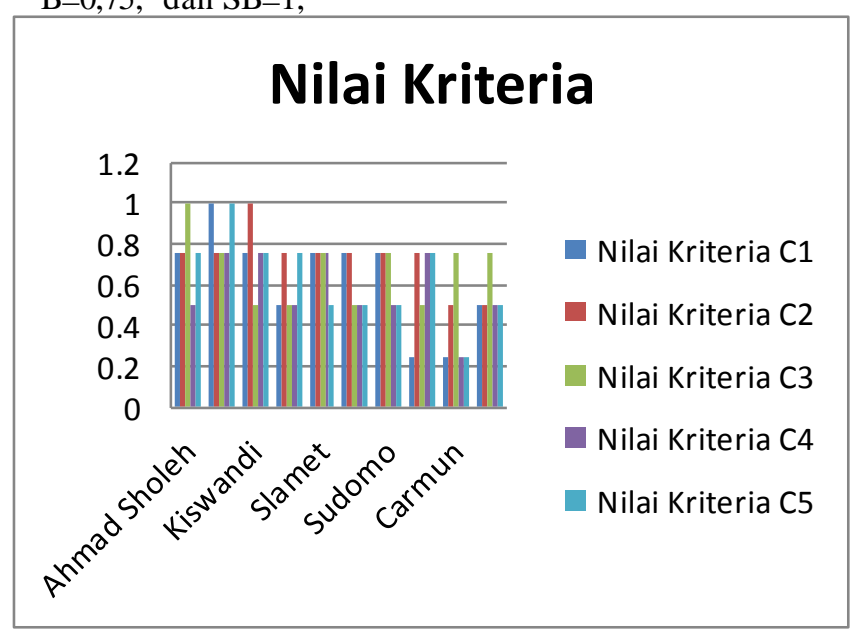

Gambar 3. Hasil konversi 10 orang pertama bilangan fuzzy kebilangan crips dari setiap alternatif pada setiap kriteria

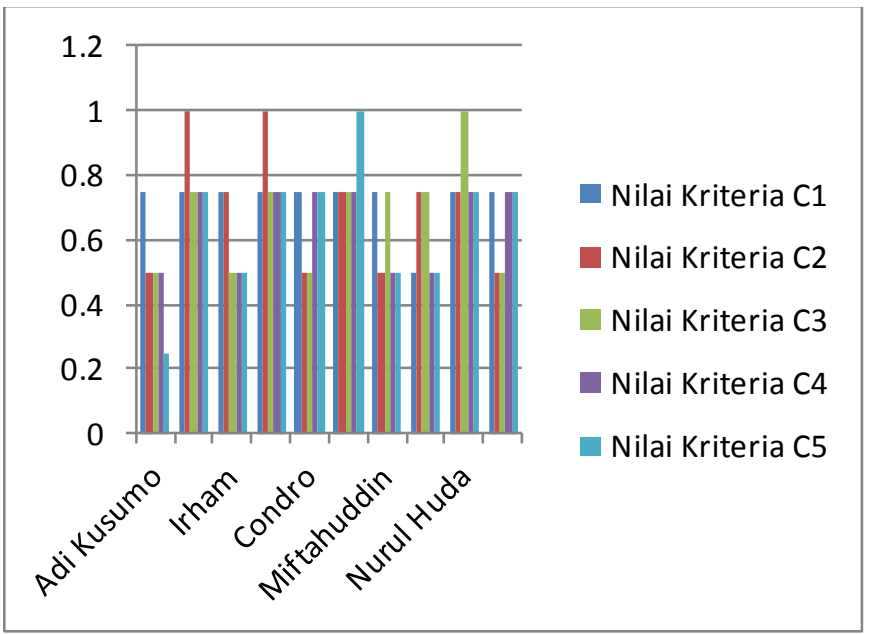

Gambar 4. Hasil konversi 10 orang kedua bilangan fuzzy kebilangan crips dari setiap alternatif pada setiap kriteria 


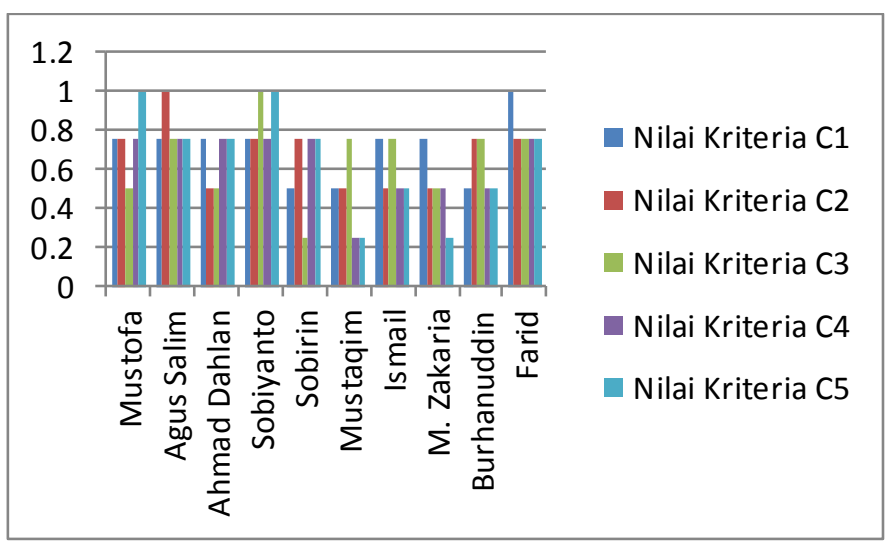

Gambar 5. Hasil konversi 10 orang ketiga bilangan fuzzy kebilangan crips dari setiap alternatif pada setiap kriteria

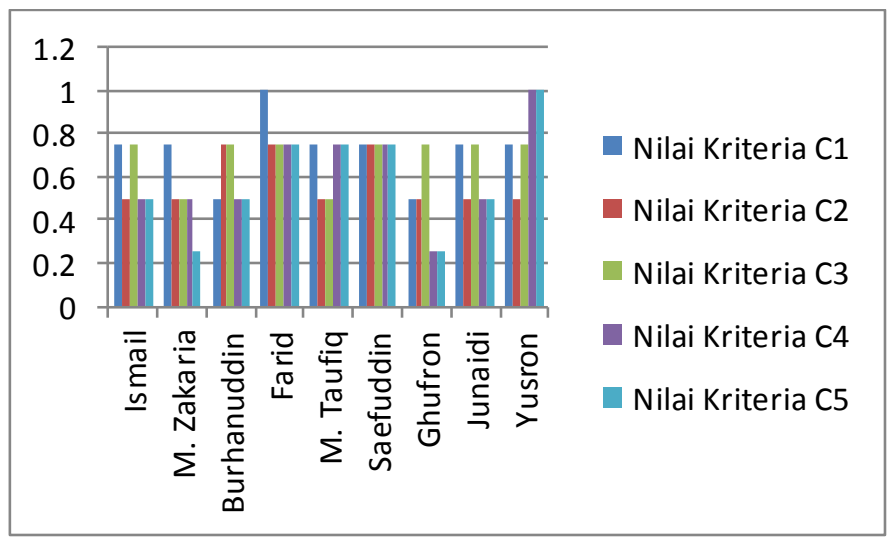

Gambar 6. Hasil konversi 5 orang keempat bilangan fuzzy kebilangan crips dari setiap alternatif pada setiap kriteria

3. Membuat matriks keputusan.

Berdasarkan tabel rating kecocokan, dapat dibentuk matriks keputusan dibentuk sebagai berikut :

$$
\begin{aligned}
& \begin{array}{lll}
0.75 & \cdots & 0.75
\end{array} \\
& X=\left[\begin{array}{lll}
\vdots & \ddots & \vdots
\end{array}\right] \\
& 0.75 \quad \cdots \quad 1
\end{aligned}
$$

Dari matriks keputusan (X) tersebut kemudian dilakukan proses normalis asi ke suatu skala yang dapat diperbandingkan dengan semua rating alternatif yang ada sesuai dengan persamaan.

4. Melakukan Perangkingan.

Setelah proses normalisasi, kemudian dihitung nilai preferensi untuk setiap alternatif $(\mathrm{Vi})$ dengan vector bobot $\mathrm{W}=[1 ; 0,75 ; 0,5 ; 0,5 ; 0,75]$ sesuai dengan persamaan 1.2:

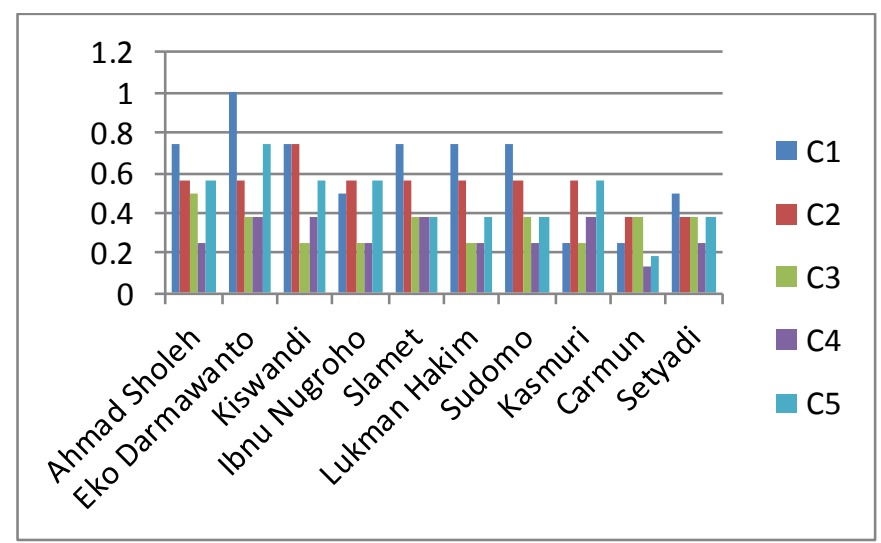

Gambar 7. Hasil perangkingan 10 orang pertama dengan FSAW

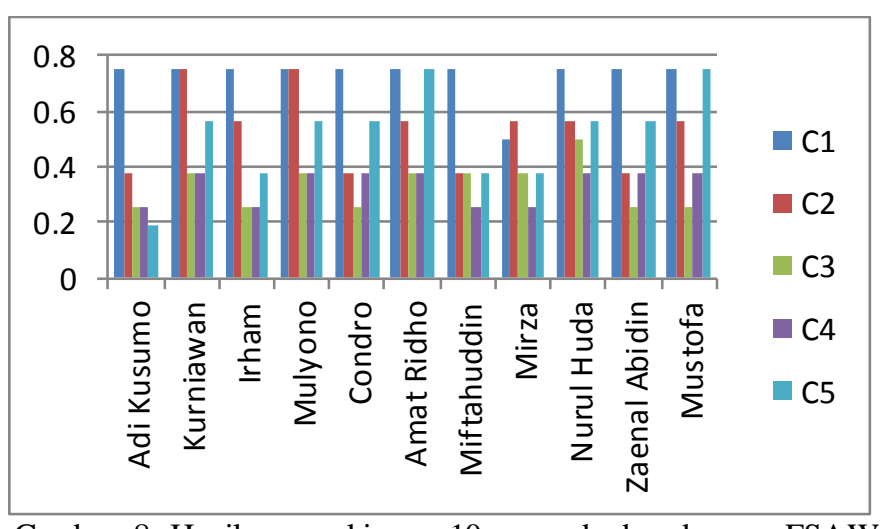

Gambar 8. Hasil perangkingan 10 orang kedua dengan FSAW

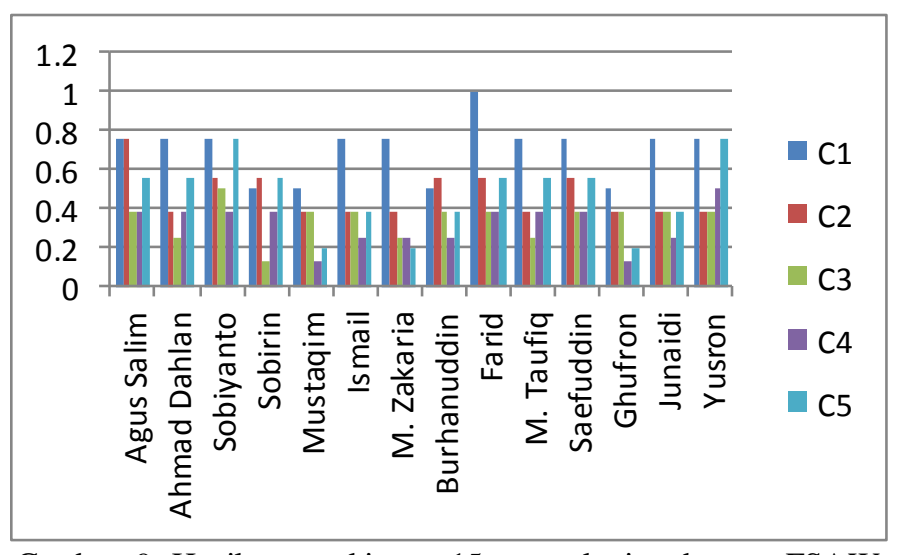

Gambar 9. Hasil perangkingan 15 orang ketiga dengan FSAW

\section{HASIL DAN PEMBAHASAN}

A. Hasil

Setelah penilaian kinerja karyawan dengan metode FSAW diimplementasikan di Ifun Jaya Textile, disebar kuesioner tahap kedua dengan responden yang sama untuk mengukur dampak implementasi sistem dengan pertanyaan dan hasilsebagai berikut :

1. Apakah sistem pendukung keputusan penilaian kinerja karyawan dengan metode FSAW dapat memberikan informasi yang lebih akurat? 
2. Apakah sistem pendukung keputusan penilaian kinerja karyawan dengan metode FSAW dapat lebih efektif untuk menilai kinerja karyawan?

3. Apakah sistem pendukung keputusan penilaian kinerja karyawan dengan metode FSAW dapat membantu perusahaan dalam pengambilan keputusan?

4. Apakah sistem pendukung keputusan penilaian kinerja karyawan dengan metode FSAW dapat digunakan secara mudah dalam melakukan penilaian prestasi kerja karyawan?

5. Apakah sistem pendukung keputusan penilaian kinerja karyawan dengan metode FSAW dapat memberikan analisis yang lebih tepat dan akurat?

6. Apakah sistem pendukung keputusan penilaian kinerja karyawan dengan metode FSAW dapat digunakan untuk menilai kinerja karyawan dengan menggunakan beberapa parameter?

7. Apakah sistem pendukung keputusan penilaian kinerja karyawan dengan metode FSAW dapat memberikan keuntungan bagi perusahaan?

Tabel 2. Hasil Post Test

\begin{tabular}{|c|c|c|c|c|c|c|c|c|c|c|}
\hline \multirow{2}{*}{ No } & \multirow{2}{*}{$\begin{array}{c}\text { Nama } \\
\text { Karya } \\
\text { wan }\end{array}$} & \multirow{2}{*}{ Jabatan } & \multicolumn{7}{|c|}{ Pertanyaan } & \\
\hline & & & 1 & 2 & 3 & 4 & 5 & 6 & 7 & \\
\hline 1 & $\begin{array}{c}\text { Puji } \\
\text { widod } \\
\text { o }\end{array}$ & Kepala kantor & 3 & 3 & 4 & 3 & 3 & 4 & 3 & 3 \\
\hline 2 & $\begin{array}{l}\text { Wulan } \\
\text { dari }\end{array}$ & $\begin{array}{c}\text { Wakil kepala } \\
\text { kantor }\end{array}$ & 3 & 3 & 3 & 4 & 4 & 4 & 3 & 4 \\
\hline 3 & Nia & kepegawaian & 3 & 3 & 3 & 3 & 3 & 4 & 3 & 2 \\
\hline 4 & $\begin{array}{c}\text { Roni } \\
\text { wahyu }\end{array}$ & Bendahara & 3 & 3 & 4 & 3 & 3 & 4 & 3 & 3 \\
\hline
\end{tabular}

Dari hasil pre test dan post test tersebut, bisa dirangkum dalam table berikut : Tabel 3. Hasil Pre Test dan Post Test.

Tabel 3. Hasil Pre-test dan Post Test

\begin{tabular}{|c|l|l|c|c|}
\hline No & \multicolumn{1}{|c|}{ Nama } & \multicolumn{1}{|c|}{ Jabatan } & $\begin{array}{c}\text { Pre } \\
\text { Test }\end{array}$ & $\begin{array}{c}\text { Post } \\
\text { Test }\end{array}$ \\
\hline 1 & Puji widodo & Kepala kantor & 16 & 23 \\
\hline 2 & Wulandari & $\begin{array}{l}\text { Wakil kepala } \\
\text { kantor }\end{array}$ & 17 & 24 \\
\hline 3 & Nia & kepegawaian & 15 & 22 \\
\hline 4 & Roni wahyu & Bendahara & 15 & 23 \\
\hline
\end{tabular}

Apabila table hasil pre test dan post test tersebut digambarkan dalam bentuk grafik, akan tampak perbedaan yang signifikan terhadap penggunaan sistem pendukung keputusan penilaian kinerja kerja karyawan dengan metode FSAW.

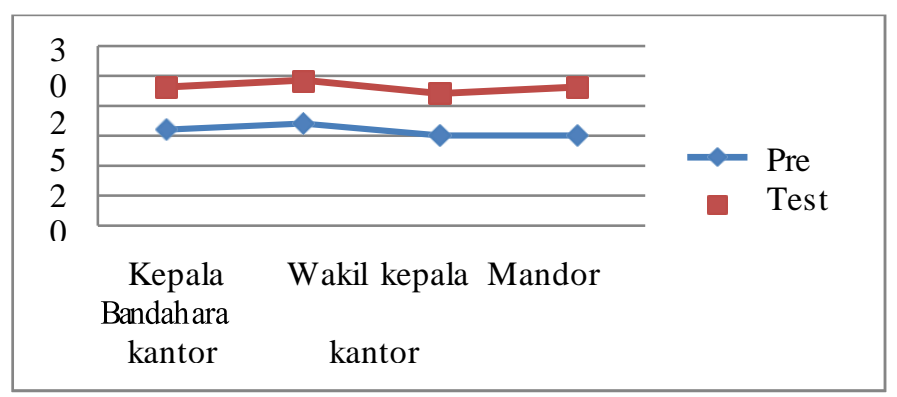

Gambar 10. Grafik hasil pre-test dan post-test

\section{B. Pembahasan}

Sebelum adanya sistem pendukung keputusan penilaian prestasi kerja karyawan, penilaian dilakukan secara manual. Setelah nilai direkap, kemudian dilakukan perhitungan dengan cara menjumlahkan nilai dari setiap kriteria, sehingga didapatkan nilai total dari setiap karyawan. Dari hasil perhitungan secara manual dan dengan menggunakan sistem Totendukung keputusan terdapat perbedaan dalam hasil perangkingan yang dilakukan. Hal ini dikarenakan pada perhitungan manual nilai total didapat dengan menjumlahkan semnua nilai pada setiap kriteria, sedangkan pada perhitungan

3 dengan sistem pendukung keputusan, dilakukan pembobotan tertetih dahulu untuk setiap kriteria, kemudian dilakukan penjumlahan nilai dari setiap kriteria. Perbedaan perangkingan terseput bisa dilihat pada gambar dibawah ini.

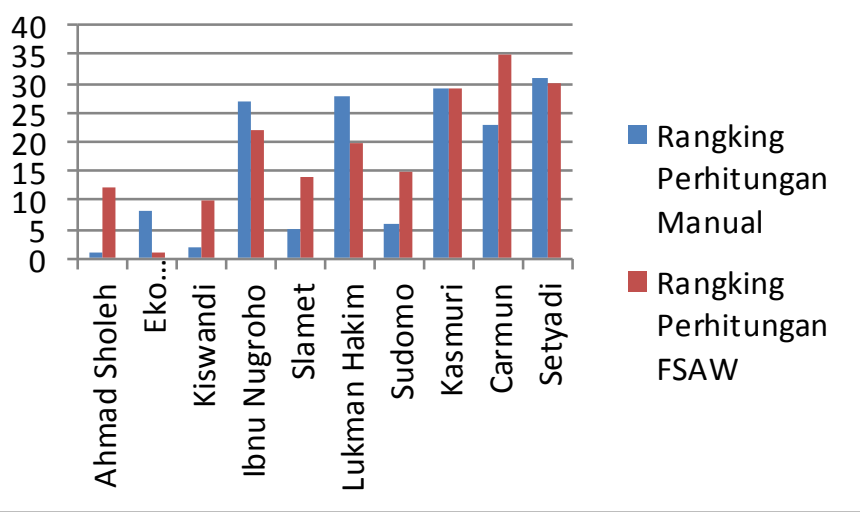

Gambar 11. Hasil Perbedaan Perangkingan pertama Perhitungan manual dan Perhitungan FSAW 


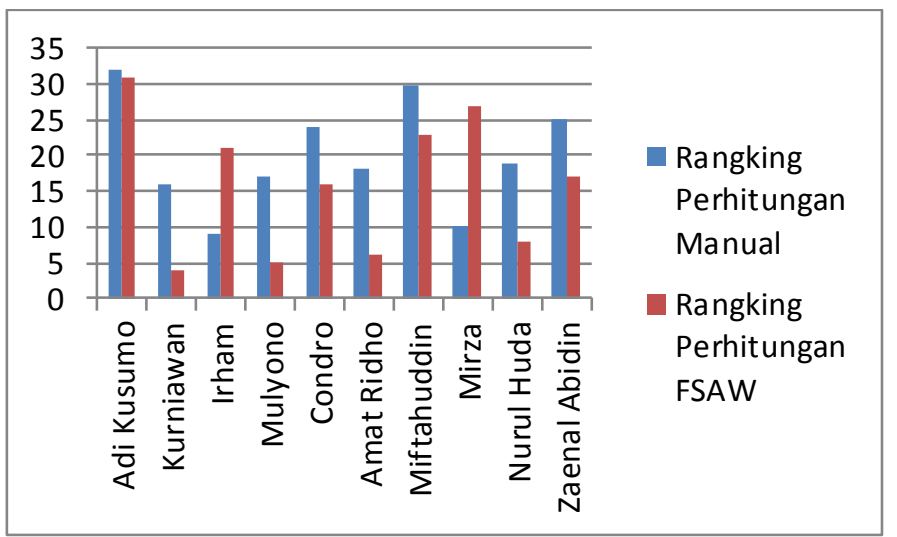

Gambar 12 Hasil Perbedaan Perangkingan kedua Perhitungan manual dan Perhitungan FSAW

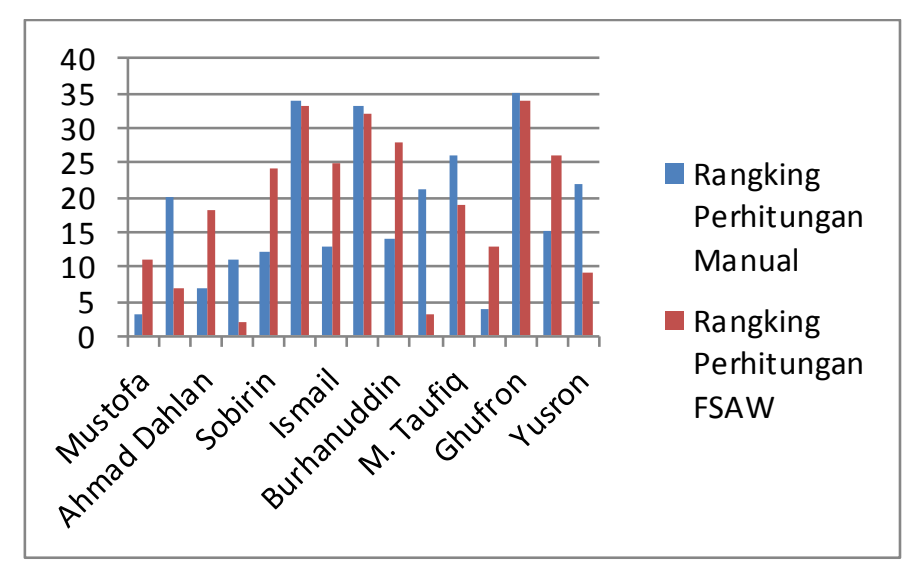

Gambar 13. Hasil Perbedaan Perangkingan ketiga Perhitungan manual dan Perhitungan FSAW

\section{KESIMPULAN DAN SARAN}

Penilaian prestasi kerja karyawan kontrak dengan parameter penilaian kualitas dan kuantitas kerja, ketaatan, kerjasama, semangat kerja dan disiplin kerja menggunakan algoritma Fuzzy Simple Additive Weighting sudah berjalan dengan baik dan dapat menghasilkan analisis dan informasi yang akurat dan cepat terlihat dibandingkan dengam perhitungan manual sehingga Rupbasan Kelas II blitar dapat mempergunakannya sebagai alat bantu untuk pengambilan keputusan.

\section{DAFTAR PUSTAKA}

[1] A. Y. Rahman, M. Sa'adah, F. W. Setiawan, and E. Supriyanto, "Vice Presidential Election Prediction Period 2019- 2024 using Simple Additive Weighting," pp. 5660, 2018.

[2] A. P. Widyassari, "Aplikasi Sistem Pendukung Keputusan Penilaian Kinerja Karyawan untuk Kenaikan Gaji Menggunakan Metode Simple Additive Weighting (SAW)," Intensif, vol. 1, no. 2, p. 92, 2017.
[3] A. Y. Rahman, M. Sa'adah, F. W. Setiawan, A. L. Hananto, and E. Supriyanto, "Access Level File using Simple Additive Weighting,” pp. 62-66, 2018.

[4] A. K. Sari, E. Sihombing, and Solikhatun, "Sistem Pendukung Keputusan untuk Meningkatkan Kualitas Pelayanan di Bidang Kesehatan,” 2017.

[5] Saefudin, "Sistem Pendukung Keputusan Untuk Penilaian Kinerja Pegawai Menggunakan Fuzzy Simple Additive Weighting (FSAW)," vol. 1, no. 1, pp. 33-37, 2018. 